\title{
A proteoliposome formulation derived from Bordetella pertussis induces protection in two murine challenge models
}

\author{
Sonsire Fernández ${ }^{*}$ Esther M Fajardo, Aleida Mandiarote, Gemma Año, Maria A Padrón, Michel Acosta, \\ Rubén A Cabrera, Luis A Riverón, Maydelis Álvarez, Kirenia Blaín, Mildrey Fariñas, Daniel Cardoso, Luis G García, \\ Concepción Campa, José L Pérez
}

From Second International Congress on Immunopharmacology 2011

Varadero Beach, Cuba. 26-30 June 2011

\begin{abstract}
Whooping cough remains a health problem despite high vaccination coverage. It has been recommended that development of new strategies provide long-lasting immunity. The aim of this work was to evaluate the potential of proteoliposomes (PL) extracted from Bordetella pertussis as a vaccine candidate against whooping cough. The size of the B. pertussis PL was estimated to be $96.7 \pm 50.9 \mathrm{~nm}$ by Scanning Correlation Spectroscopy and the polydispersity index was 0.268 . Western blots using monoclonal antibodies revealed the presence of pertussis toxin, pertactin, and fimbriae 3. The Limulus Amebocyte Lisate (LAL) assay showed endotoxin levels lower than those reported for whole cell pertussis licensed vaccines, while the Pyrogen Test indicated $75 \mathrm{ng} / \mathrm{mL} / \mathrm{Kg}$. The PL showed high protection capacity in mouse challenge models. There was $89.7 \%$ survival in the intracerebral challenge and total reduction of the number of CFU in the intranasal challenge. No significant differences $(p>0.05)$ were observed between mice immunized with $B$. pertussis PL and the Cuban DTwP vaccine, whichever challenge model used. These results encouraged us to continue the development of the $B$. pertussis PL as a component of a new combined vaccine formulated with tetanus and diphtheria toxoids or as a booster dose for adolescents and adults.
\end{abstract}

\section{Introduction}

Whooping cough remains an important cause of public health concern worldwide. Data from WHO revealed that more than 16 million cases and about 195000 deaths were reported in 2008 [1]. Despite high vaccination coverage with whole-cell ( $\mathrm{wP}$ ) or acellular (aP) vaccines, pertussis is still prevalent, probably in part, as a result of waning immunity and for that reason new vaccine strategies, able to provide long-lasting immunity have been recommended [2]. Bacterial-derived proteoliposomes (PL) are nanoparticulate vesicular structures that contain proteins, lipids and native lipopolysaccharide (LPS). To date, only a few licensed PLbased vaccines are available. One of them is VA-MENGOC-BC ${ }^{\circledR}$, a vaccine composed of PL obtained from the outer membrane of Neisseria meningitidis serogroup B.

\footnotetext{
* Correspondence: sfernandez@finlay.edu.cu

Research \& Development Vice-presidency, Finlay Institute. Havana, Cuba
}

This PL has been shown to have high efficacy in controlling meningococcal disease [3] and has also exhibited potent adjuvant activity when used with other vaccine antigens not only in its native form, but in cochleate form too [4]. Thus, a PL derived from $B$. pertussis could be a good approach for a new candidate vaccine against whooping cough.

\section{Materials and methods}

Cellular pellets of $B$. pertussis strain 165 grown at industrial scale, inactivated with formalin $0.1 \%$ through $48-56$ hours, were homogenized with $30 \mathrm{mM}$ Tris buffer, containing $2 \mathrm{mM}$ EDTA, $\mathrm{pH} 8.5$ at a ratio of $100-200 \mathrm{mg} /$ $\mathrm{mL}$. Sodium deoxycholate (Fluka, Switzerland) was added at a ratio of $0.1-1 \mathrm{~mL} / \mathrm{g}$ of biomass. The mixture was incubated for 1 hour and centrifuged at $33000 \mathrm{~g}$ for $15 \mathrm{~min}$. All supernatants were collected, subjected to a sequence of diafiltration processes and filtered using a
Ciomed Central 
Sartorius Minisart-plus unit of $0.2 \mu \mathrm{m}$. Particle size PL was determined by Photon Correlation Spectroscopy (PCS) (Beckman Coulter, Hialeach, FL, US). SDS-PAGE (polyacrylamide 13\%) followed by a R250 Blue Coomassie or silver stain for LPS [5,6] was carried out using a low molecular weight marker (Amersham, UK). Western blot assays [7] were carried out using monoclonal antibodies (Mabs) against pertussis toxin (PT), pertactin (PRN) and fimbriae 3 (FIM3) (NIBSC, UK). The biological activity of the endotoxin present in the PL was determined by Limulus Amebocyte Lisate (LAL) [8] and by a Total Pyrogen Test in rabbits [9] at 10, 25, 50, 75 $\mathrm{ng} / \mathrm{mL}$ concentrations of protein. Intracerebral challenge assays were carried out in 4-6 weeks old, 16-18 g, female OF1 mice (CENPALAB, Cuba) injected intraperitoneally with one dose of $0.5 \mathrm{~mL}$ of $60 \mu \mathrm{g}$ of PL and aluminum hydroxide $(1 \mathrm{mg} / \mathrm{mL})$, DTwP vaccine (Finlay Institute) prepared at $8 \mathrm{Ul} / \mathrm{mL}$ or placebo. Intracerebral challenge with $B$. pertussis 18323 (100-1000 $\left.\mathrm{DL}_{50}\right)$ was performed 2 weeks post immunization. All mice were observed for 14 days after the challenge and daily mortality was registered. For the intranasal challenge assay, $\mathrm{BALB} / \mathrm{c}$ mice (female, 3-4 weeks, 12-14 g, CENPALAB, Cuba) were immunized subcutaneously with 2 doses, $125 \mu \mathrm{L}$ separated by a three-week interval. Each dose consisted of $20 \mu \mathrm{g}$ of PL and $0.25 \mathrm{mg}$ of aluminum hydroxide. A group of mice was immunized with $125 \mu \mathrm{L}$ of DTwP vaccine (Finlay Institute) while another group received $125 \mu \mathrm{L}$ of PBS and aluminum hydroxide as placebo. The intranasal challenge and lung extraction was performed following the procedure described by Guiso et al. [10]. Results were expressed as the average $\log _{10}$ of the CFU/g of lung for each group of mice at each extraction time after challenge.

\section{Statistical analysis}

The Wilson approximate method and software R 2.10.0 [11] were used to calculate the confidence intervals. The arithmetic means \pm standard deviation for $\log _{10} \mathrm{CFU} /$ lung were also calculated. The comparison of arithmetic means of the groups was carried out by an analysis of simple variance (Statistic kit, Statgraphics Plus 5.0).
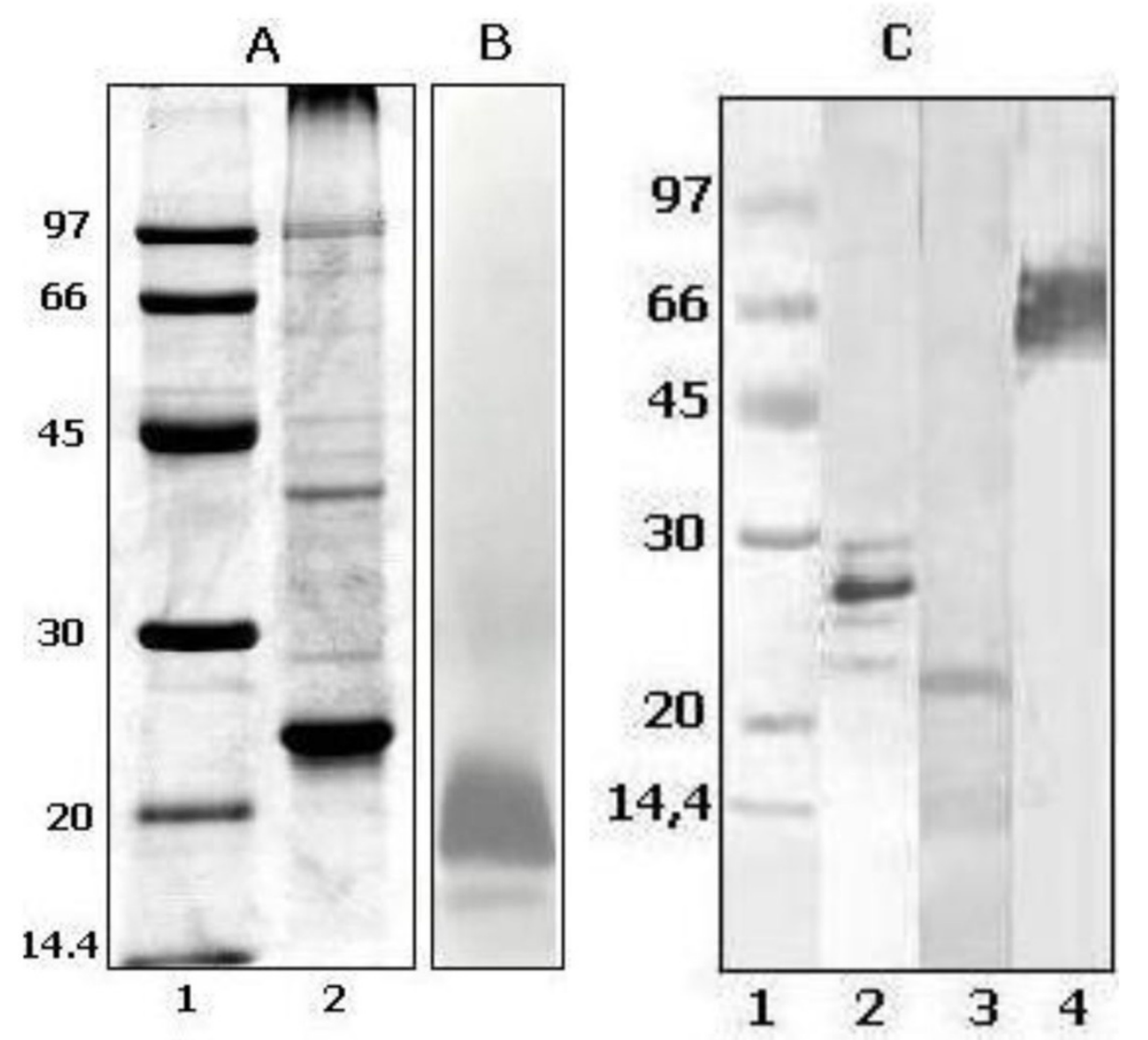

Figure 1 B. pertussis PL composition analysis; Panel A, SDS-PAGE (polyacrylamide 13\%) followed by R250 Blue Coomasie stain. Lane 1: Low molecular weight markers (97-14.4 kDa), Lane 2: B. pertussis PL. Panel B, SDS-PAGE of B. pertussis PL (polyacrylamide $13 \%$ ) followed by a LPS-specific silver stain. Panel C, Western blot of $B$. pertussis PL using Mabs or serum vs relevant antigens; Lane 1: Low molecular weight markers (97-14.4 kDa), Lane 2: PT anti serum (97/572), Lane 3: FIM 3 Mab (04/156), Lane 4: PRN anti serum (97/558). 


\section{Results and discussion}

Sodium deoxycholate was used to extract proteoliposomes from the outer membranes of inactivated cells of B. pertussis strain 165 . The size of the PL was estimated to be $96.7 \pm 50.9 \mathrm{~nm}$ with a polydispersity index of 0.268. SDS-PAGE (Figure 1 panels A and B) suggests the presence of molecules such as LPS and outer membrane proteins. Western blot assays using Mabs showed the presence of PT, FIM 3 and PRN (Figure 1 panel C), all of them are protective antigens present in acellular vaccines [12]. Proteomic and western blot studies with other Mabs are planed to completely elucidate the antigenic composition of $B$. pertussis PL. The biological activity of the endotoxin in PL was evaluated by the LAL method and showed a value of $4960 \mathrm{EU} /$ dose or 9 $920 \mathrm{EU} / \mathrm{mL}$. The endotoxic activity was higher than those reported for licensed aP vaccines $(38-1390 \mathrm{EU} /$ $\mathrm{mL}$ ), but lower than those reported for some licensed $\mathrm{wP}$ vaccines (11 $400-181100 \mathrm{EU} / \mathrm{mL})$ [13], and similar to the meningococcal vaccine MenB $(\leq 20000 \mathrm{EU} / \mathrm{mL})$ which consists of outer membrane vesicles [14]. In addition, the PL were non pyrogenic at concentrations less than or equal to $75 \mathrm{ng} / \mathrm{mL} / \mathrm{Kg}$ of weigh of rabbits, according to the Total Pyrogen Test.

Mice immunized with both, the PL and DTwP vaccine, showed high protection levels against intracerebral challenge [ $89.7 \%$ and 91.2 of survival, respectively ( $95 \%$ confidence in the interval 76.4-95.9\%)]. These values were significantly different in relation to the placebo group [12.1\% of survival (95\% confidence in the interval $4.8-$ $27.3 \%)]$ and there were no differences between them $(\mathrm{P}<0.05)$. No mice died during the assay due to post-challenge trauma. Protective capacity induced by PL and DTwP vaccine, was also estimated by intranasal challenge (Table 1). Four days after challenge, no CFU were counted in lungs of mice immunized with PL or DTwP vaccine. Conversely, the number of CFU recovered from lungs of mice belonging to the Placebo group, at 4 and 7 days, was significantly $(\mathrm{P}<0.05)$ high compared with the other two groups. Overall, these results clearly indicate the potential of $B$. pertussis PL as a vaccine candidate against whooping cough.

Table 1 Intranasal challenge experiments in BALB/c mice using $B$. pertussis WHO reference strain 18323

\begin{tabular}{lccc}
\hline & \multicolumn{3}{c}{$\begin{array}{c}\text { Bacteria recovered post challenge (Log CFU/g lung } \\
\mathbf{\pm} \text { S.D.) }\end{array}$} \\
\cline { 2 - 4 } & $\mathbf{2}$ hrs & $\mathbf{4}^{\text {th }}$ day & $\mathbf{7}^{\text {th }}$ day \\
\hline DTwP vaccine & $7.85 \pm 0.39$ & $\mathrm{NR}$ & $\mathrm{NR}$ \\
\hline B. pertussis PL & $6.68 \pm 0.65$ & $\mathrm{NR}$ & $\mathrm{NR}$ \\
\hline PBS & $8.02 \pm 0.2$ & $6.85 \pm 0.44$ & $6.48 \pm 0.11$ \\
\hline
\end{tabular}

NR. Not recovered

\section{Authors' contributions}

SF conceived of the study, and participated in its design, carried out the purification of proteoliposomes, participated in the animal studies, and drafted the manuscript; EMF participated in the animal studies and helped in the revision of the manuscript; AM participated in the animal studies and in the analytical procedures; GA participated in the design of the study; MAP participated in the analytical procedures; MA participated in the analytical procedures; RAC participated in the analytical procedures; LAR participated in the purification of proteoliposomes; MA participated in the purification of proteoliposomes and in the animal studies; KB participated in the analytical procedures; MF participated in the animal studies; DC supplied the cellular biomass; LGG participated in the revision of the manuscript; CC participated in the revision of the manuscript; JLP conceived of the study, and participated in its design, carried out the purification of proteoliposomes, participated in the animal studies, and revised the manuscript.

\section{Competing interests}

The authors declare that they have no competing financial interests.

\section{Acknowledgements}

The authors want to give thanks to MSc Vladimir Peña for the technical support provided in the particle size analysis of PL. We also acknowledge Dr. Reinaldo Acevedo for useful suggestions.

\section{Declarations}

This article has been published as part of BMC Immunology Volume 14 Supplement 1, 2013: Proceedings from Delivery Systems and Current strategies to drug design. The full contents of the supplement are available online at http://www.biomedcentral.com/bmcimmunol/supplements/14/S1.

Published: 25 February 2013

\section{References}

1. W.H.O.-World Health Organization: Pertussis vaccines: W.H.O. position paper. Wkly Epidemiol Rec 2010, 85:385-400.

2. Storsaeter J, Wolter J: Is there a need for a new generation of vaccines against pertussis? Expert Opin Emerg Drugs 2006, 11(2):195-205.

3. Sotolongo F, Campa C, Casanueva V, Fajardo EM, Cuevas IE, González N: Cuban Meningococcal BC Vaccine: Experiences \& Contributions from 20 Years of Application. MEDICC Rev 2007, 9(1):16-22.

4. Perez O, Bracho G, Lastre M, Mora N, del Campo J, Gil D, Zayas C, Acevedo R, Gonzalez D, Lopez J, et al: Novel adjuvant based on a PLderived cochleate structure containing native lipopolysaccharide as a pathogen associated molecular pattern. Immunol Cell Biol 2004 82(6):603-610.

5. Tsai CM, Frash CE: A sensitive silver stain for detecting lipopolysaccharides in polyacrylamide gels. Anal Biochem 1982, 119(1):115-119.

6. Laemmli NK: Clearage of structural proteins during the assembly of the head of bacterio phage T4. Nature 1970, 227:680-685.

7. Wedege E: Immunoblot analysis of sera from patients and vaccinees. In Methods in molecular medicine, Meningococcal vaccines. Methods and Protocols. New Jersey: Human Press Inc;Pollard A, Maiden MCJ 2001:275-288.

8. United States Pharmacopoeia: Bacterial Endotoxins Test (85). USP 30-NF25 The United States Pharmacopoeia. Rockville, MD: USP Convention; 2007, 109-112

9. United States Pharmacopoeia: Pirogen Test (151). USP 31-NF26 The United States Pharmacopoeia. Rockville, MD: USP Convention; 2008.

10. Guiso N, Capiau C, Poolman J, Hauser P: Intranasal murine model of Bordetella pertussis infection. I. Prediction of protection in human infants by acellular vaccines. Vaccine 1999, 17:2366-2376.

11. R Development Core Team: R: A language and environment for statistical computing. R Foundation for Statistical Computing, Vienna, Austria;3900051-07-0 2009 [http://www.R-project.org]

12. Mattoo S, Cherry J: Molecular pathogenesis, epidemiology and clinical manifestations of respiratory infections due to Bordetella pertussis and other Bordetella subspecies. Clin Microbiol Rev 2005, 18(2):326-382.

13. Geier DA, Geier MR: Clinical implications of endotoxin concentrations in vaccines. Ann Pharmacother 2002, 36:776-780.

14. Frasch CE, van Alphen L, Holst J, Poolman JT, Rosenqvist E: Outer membrane Vesicle Vaccines for Meningococcal Disease. In Meningococcal 
Vaccines. Methods and Protocols. New Jersey: Human Press Inc;Pollard AJ, Maiden MCJ 2001:81-107

doi:10.1186/1471-2172-14-S1-S8

Cite this article as: Fernández et al: A proteoliposome formulation derived from Bordetella pertussis induces protection in two murine challenge models. BMC Immunology 2013 14(Suppl 1):S8.

Submit your next manuscript to BioMed Central and take full advantage of:

- Convenient online submission

- Thorough peer review

- No space constraints or color figure charges

- Immediate publication on acceptance

- Inclusion in PubMed, CAS, Scopus and Google Scholar

- Research which is freely available for redistribution

Submit your manuscript at www.biomedcentral.com/submit
C Biomed Central 